\title{
URGENSI TANDA TANGAN DAN MATERAI DALAM MEMBERIKAN KEPASTIAN HUKUM TERHADAP KONTRAK WARALABA (FRANCHISE)
}

\author{
Erwin Kusnul Kotimah \\ Fakultas Syariah dan Hukum IAIN Ponorogo \\ Email: erwincusma@gmail.com \\ Lukman Santoso \\ Fakultas Syariah dan Hukum IAIN Ponorogo \\ Email: lukmansantoso4@gmail.com
}

\begin{abstract}
This article explanes about urgency of signatures and stamp duty in giving legal certainty to the franchise contract. This theme departs from the rise of business model franchise today in Indonesia. This business is considered to minimize the risk of failure, as well as to provide various facilities. This research is a descriptive analytical research. In franchise contract are still many things that can happen in the future that might be detrimental to the parties. Therefore we need the legal umbrella to shade and protect with the aim to create a sense of fairness and legal certainty for the parties, not just for profit (profit oriented), but there is accountability for the impact of the overall business operations. To provide legal certainty every contract franchise must be in writing and include the signature and the stamp in order to obtain a force of law and can be evidence, so the purpose of legal certainty can be realized.
\end{abstract}

Keywords: Signature, Stamp, Rule of Law, franchise

\begin{abstract}
Abstrak
Artikel ini mengkaji tertang urgensi tanda tangan dan materai dalam memberikan kepastian hukum terhadap kontrak waralaba. Tema ini berangkat dari maraknya bisnis dengan model franchise dewasa ini di Indonesia. Bisnis ini dianggap dapat meminimalisir resiko kegagalan, selain juga dapat memberikan berbagai kemudahan. Penelitian ini merupakan jenis penelitian deskriptif analitis. Dalam kontrak franchise masih banyak hal-hal yang dapat terjadi di masa yang akan datang yang mungkin dapat merugikan para pihak. Oleh karena itu diperlukan adanya payung hukum untuk menaungi dan melindungi dengan tujuan untuk mewujudkan rasa keadilan dan kepastian hukum bagi para pihak, bukan hanya sekedar mencari keuntungan (profit oriented) tetapi ada pertanggungjawaban terhadap dampak yang ditimbulkan dari operasional bisnis secara menyeluruh tersebut. Untuk memberikan kepastian hukum setiap kontrak franchise harus dibuat secara tertulis dan dilengkapi dengan tanda tangan serta materai agar diperoleh suatu kekuatan hukum dan dapat menjadi alat bukti, sehingga tujuan kepastian hukum dapat terwujud.
\end{abstract}

Keywords: Tanda Tangan, Materai, Kepastian Hukum, franchise

\section{Pendahuluan}

Dewasa ini, dampak dari perkembangan zaman yang begitu pesat nampak terlihat pada sektor perekonomian, dimana pada sektor ekonomi ini terjadi bermacam-macam persaingan yang bahkan tidak lagi mengenal batas-batas wilayah. Salah satu sistem bisnis yang saat ini tengah marak berkembang di masyarakat adalah bisnis franchise.

Franchise atau waralaba adalah sebuah sistem bisnis alih teknologi (transfer of technology) yang dilakukan di bidang hak kekayaan intelektual seperti Paten, Merek, Rahasia Dagang, Desain Industri dan lain sebagainya yang bertujuan komersial. ${ }^{1}$

Bisnis model ini tumbuh subur di Indonesia, baik yang ber merek asing maupun merek lokal atau dalam negeri. Cepatnya perkembangan dan

1 Lannemey, "Akibat Hukum Pemutusan Perjanjian Franchise Secara Sepihak Oleh Franchisor Sebelum Berakhirnya Kontrak", Lex Privatum, Vol. III, No. 1 (Jan-Mar 2015), h. 163. 
suksesnya bisnis franchise ini disebabkan oleh beberapa faktor. Faktor yang paling mendasar adalah bahwa franchise merupakan kombinasi dari pengetahuan dan kekuatan satu usaha bisnis yang sudah ada atau mapan.

Sistem usaha franchise atau waralaba dilakukan dengan melibatkan dua pihak, yaitu pemberi waralaba (franchisor) dan penerima waralaba (franchisee). Di satu sisi franchisor memberikan lisensi menggunakan suatu Hak Kekayaan Intelektual seperti Hak Cipta, Merek, Paten, Rahasia Dagang kepada franchisee. Di sisi lain franchisee berkewajiban untuk membayar royalty fee terhadap franchisor atas lisensi yang diberikan.

Hubungan hukum antara franchisor dan franchisee ini kemudian diwujudkan dalam suatu perjanjian franchise yang mana antara kedua pihak tersebut mempunyai kedudukan hukum yang setara dan terhadap mereka berlaku hukum Indonesia. Sebagaimana diatur dalam Pasal 5 Peraturan Menteri Perdagangan Republik Indonesia Nomor 53/M-DAG/PER/8/2012 tentang Penyelenggaraan Waralaba. ${ }^{2}$

Pemerintah telah mengatur sistem waralaba secara khusus dalam Peraturan Pemerintah Nomor 42 tahun 2007 tentang Waralaba (Franchise) yang telah diundangkan pada tanggal 23 Juli 2007 dalam rangka untuk memberikan kepastian hukum dan perlindungan hukum dalam menjalankan usaha franchise. Hal itu dilakukan karena Pemerintah beranggapan bahwa sistem franchise ini merupakan salah satu cara yang efektif untuk memacu pertumbuhan kegiatan ekonomi negara dan memberikan kesempatan kepada masyarakat khususnya golongan ekonomi lemah untuk berusaha menjalankan bisnis dengan resiko yang relatif kecil.

Pengaturan franchise atau waralaba melalui peraturan pemerintah saja tidaklah cukup untuk memberikan perlindungan hukum bagi kedua belah pihak antara franchisor (pemberi waralaba) dan franchisee (penerima waralaba), mengingat perkembangan franchise di Indonesia yang menjadi suatu usaha yang sangat menarik perhatian bagi pelaku usaha, sehingga perlu dibuat suatu undangundang tentang waralaba.

Perjanjian franchise merupakan kesepakatan yang dibuat oleh kedua belah pihak antara pemberi waralaba (franchisor) dan penerima waralaba (franchisee), secara tertulis yang memuat

${ }^{2}$ Ibid., h. 162. hak dan kewajiban masing-masing pihak serta akibat hukum yang harus dipatuhi oleh para pihak. Dalam kesepakatan tertulis tersebut, para pihak baik franchisor maupun franchisee menyatakan kesepakatannya dalam bentuk penulisan atau pencantuman tanda tangan. Hal ini penting adanya agar kontrak tersebut dinyatakan sah. Karena salah satu asas dalam perikatan adalah adanya konsensus atau kesepakatan. Namun suatu realitas yang tidak dapat dipungkiri bahwa dalam masyarakat Indonesia sampai saat ini belum bebas dari buta huruf, yang dengan kondisi demikian masih sering ditemukan dalam praktek perjanjian/kontrak terdapat para pihak yang tidak bisa membaca dan menulis sehingga mereka membubuhkan cap jempol/ibu jari sebagai pengganti tanda tangannya.

Lazimnya dalam praktik keseharian, selain tanda tangan setiap surat perjanjian selalu menyertakan materai. Pembubuhan tanda tangan dan materai tersebut tidak lain adalah untuk memberikan kepastian hukum dalam surat perjanjian tersebut. Agar apabila suatu saat terjadi perselisihan atau sengketa dalam pelaksanaan isi perjanjian waralaba tersebut, masing-masing pihak dapat menuntut haknya yang telah dilanggar oleh pihak lain tersebut.

Namun dalam masyarakat seringkali terjadi kesalahpahaman tentang esensi materai dalam sebuah surat perjanjian/kontrak. Alasannya penggunaan materai dalam surat kontrak tersebut tiada lain adalah untuk keabsahan dari surat kontrak itu. Masyarakat cenderung menggunakan materai sebagai indikator dalam menentukan sah atau tidaknya suatu surat perjanjian. ${ }^{3}$

Saat ini banyak masyarakat yang beranggapan bahwa perjanjian/kontrak yang hanya ditandatangani saja tanpa meterai, maka perjanjian/kontrak yang dibuat tidak sah. Dan karena keyakinan masyarakat akan hal tersebut, tidak sedikit masyarakat yang rela membuat ulang perjanjian mereka hanya karena kelupaan dalam pemberian atau pelunasan meterai dalam kontrak yang dibuat. Selain itu ada juga masyarakat yang tidak mau memenuhi janjinya sebagaimana yang dituangkan dalam perjanjian yang telah dibuat dengan alasan perjanjian yang dibuat itu tidak sah karena tidak ada meterainya. ${ }^{4}$

\footnotetext{
3 Mega Tumilaar, "Fungsi Meterai Dalam Memberikan Kepastian Hukum Terhadap Surat Perjanjian", Lex Privatum, Vol. III, No. 1 (Jan-Mar 2015), h. 60.

${ }^{4}$ Ibid., h. 58.
} 
Perlu diketahui dan dipahami oleh masyarakat bahwa ada atau tidaknya meterai dalam sebuah perjanjian bukanlah suatu syarat yang menjadi parameter untuk mengatakan suatu perjanjian itu menjadi sah atau tidak sah.

Terkait realita di atas penting kiranya memahami kedudukan tanda tangan dan materai dalam kontrak franchise, maka penulis melalui artikel berupaya mengelaborasi secara komprehensif dengan perspektif analisa yuridis dengan tema "Fungsi Tanda Tangan dan Meterai dalam Memberikan Kepastian Hukum Terhadap Kontrak Waralaba".

\section{Pembahasan}

\section{Konsepsi Tanda Tangan dan Materai}

Dalam Bahasa Belanda tanda tangan berasal dari kata ondertekenen yang berarti "membuat tanda di bawah". Arti kata "menandatangani" (ondertekenen) secara etimologis mudah ditemui, yaitu memberi tanda (teken) dibawah sesuatu. ${ }^{5}$

Tanda tangan adalah suatu pernyataan kemauan pembuat tanda tangan (penandatanganan), bahwa ia dengan membubuhkan tanda tangannya di bawah suatu tulisan menghendaki agar tulisan itu dalam hukum dianggap sebagai tulisannya sendiri. Definisi tersebut mencakup suatu anggapan, bahwa pada pernyataan yang dibuat secara tertulis harus dibubuhkan tanda tangan dari yang bersangkutan.

Arrest Hoge Raad tanggal 16 Mei 1846, memutus bahwa persyaratan penandatanganan hanya terpenuhi dengan membubuhkan "nama yang dipakai oleh penandatangan", dengan atau tanpa menambahkan nama kecilnya. Sedang dari beberapa pasal Notaris Reglement yang memuat tentang ketentuan syarat penandatanganan akta, dapat ditemukan petunjuk, bahwa yang dimaksud "tanda tangan" adalah tanda tangan nama. Oleh karena itu, seharusnya dari suatu tanda tangan dapat diketahui atau dibaca siapa nama pemilik tanda tangan tersebut. Tetapi mengenai syarat bahwa tanda tangan dapat dibaca, tidak terdapat dalam ketentuan perundang-undangan. Konsekuensinya adalah bahwa tanda tangan yang tidak dapat dibaca/ diketahui nama pemiliknya tetap memenuhi syarat sebagai tanda tangan. ${ }^{6}$

\footnotetext{
${ }^{5}$ Hadi Suwignyo, "Keabsahan Cap Jempol Sebagai Pengganti Tanda Tangan Dalam Pembuatan Akta Otentik", Jurnal Studi Kenotariatan NOTARIUS, Vol. 1, No. 1 (2009), h. 5.

' Paulus J. Soepratignja, Teknik Pembuatan Akta Kontrak.
}

Penandatanganan suatu dokumen secara umum mempunyai tujuan sebagai berikut: ${ }^{7}$

1. Sebagai bukti (evidence)

Suatu tanda tangan mengidentifikasikan penandatanganan dokumen yang ditandatanganinya. Pada saat penandatanganan membubuhkan tanda tangan dengan bentuk yang khusus, tulisan tersebut akan mempunyai hubungan (attribute) dengan penandatanganan.

2. Sebagai ceremony

Penandatanganan suatu dokumen akan berakibat bahwa si penandatangan tahu dan mengerti bahwa ia melakukan perbuatan hukum, sehingga akan mengeliminasi adanya inconsiderate engagement.

3. Sebagai persetujuan

Tanda tangan melambangkan adanya persetujuan atau otoritasi terhadap suatu tulisan.

Pengertian tanda tangan dalam arti umum, adalah tanda tangan yang dapat didefinisikan sebagai suatu susunan (huruf) tanda berupa tulisan dari yang menandatangani, yang mana orang yang membuat pernyataan/keterangan tersebut dapat diindividualisasikan. ${ }^{8}$

Keharusan adanya tanda tangan tidak lain bertujuan untuk membedakan akta yang satu dari akta yang lain atau dari akta yang dibuat orang lain. Jadi fungsi tanda tangan tidak lain adalah untuk memberi ciri atau untuk mengindividualisir sebuah akta karena identifikasi dapat dilihat dari tanda tangan yang dibubuhkan pada akta tersebut. Yang dimaksudkan dengan penandatangan dalam akta ini adalah membubuhkan nama dari si penandatangan, sehingga membubuhkan paraf, yaitu singkatan tanda tangan saja dianggap belum cukup, nama tersebut harus ditulis tangan oleh si penandatangan sendiri atas kehendaknya sendiri. ${ }^{9}$

Sementara itu, bagi orang yang buta huruf dan karena itu tidak dapat menuliskan namanya sendiri (dalam bentuk tanda tangan), menurut

(Yogyakarta: Universitas Atma Jaya, 2007), h. 134.

7 Lukman Santoso AZ, Hukum Perikatan (Malang: Setara Press, 2016), h. 114.

8 Tutwuri Handayani, "Pengakuan Tanda Tangan Pada Suatu Dokumen Elektronik Di Dalam Pembuktian Hukum Acara Perdata Di Indonesia", Tesis Universitas Diponegoro Semarang (2009), h. 35.

9 Hadi Suwignyo, "Keabsahan Cap Jempol Sebagai Pengganti Tanda Tangan Dalam Pembuatan Akta Otentik", Jurnal Studi Kenotariatan Notarius, Vol. 1, No. 1, (200), h. 2. 
Pasal 1 dari Ordonasi tanggal 14 Maret 1867, pembubuhan suatu "teraan ibu jari" (cap jempol), dapat dipersamakan dengan penandatanganan surat di bawah tangan, asal diikuti dengan legalisasi oleh seorang notaris atau pejabat lain yang ditunjuk oleh undang-undang. Bunyi ketentuan pasal itu sesuai dengan ketentuan Pasal 1874 ayat (2) KUHPerdata serta Pasal 286 ayat (2) RBg. ${ }^{10}$

Tetapi penggunaan cap jempol tidak semudah dalam penggunaan penandatangan untuk suatu akta/surat. Oleh karena untuk sah dan sempurnanya cap jempol harus memenuhi beberapa syarat antara lain: ${ }^{11}$

1. dilegalisasi oleh pejabat yang berwenang;

2. dilegalisasi diberi tanggal;

3. pernyataan dari pejabat yang melegalisasi, bahwa orang yang membubuhkan cap jempol dikenal atau diperkenalkan kepadanya;

4. isi akta telah dijelaskan kepada yang bersangkutan;

5. pembubuhan cap jempol dilakukan di hadapan pejabat tersebut.

Kekuatan cap jempol rupanya lebih rumit agar mendapat kekuatan hukum yang sempurna. Padahal dari segi kepastian hukum cap jempol lebih kuat kepastian hukumnya dibandingkan dengan tanda tangan. Bukankah banyak hasil penelitian mengatakan bahwa sidik jari yang dimiliki setiap orang berbeda dengan yang dipunyai oleh orang lain. Artinya niat jahat dari seseorang untuk memalsukannya tidak gampang. Beda halnya dengan tanda tangan yang dengan begitu mudah dipalsukan. Oleh sebab itu kurang tepat kiranya jika ada yang mengatakan bahwa kekutan hukum cap jempol tidak dapat disamakan dengan kekutan hukum yang melekat dalam sebuah tanda tangan.

Bukti tertulis berupa surat perjanjian merupakan salah satu alat bukti yang dapat digunakan pada saat persidangan dalam perkara perdata terutama mengenai perjanjian. Surat perjanjian tersebut dapat dikategorikan dalam pengertian akta. Akta adalah surat yang dibuat dan ditandatangani serta memuat peristiwa-peristiwa yang menjadi dasar suatu hak atau perikatan yang sejak semula memang sengaja dimaksudkan untuk pembuktian. Jadi untuk dapat digolongkan

\footnotetext{
${ }^{10}$ Paulus J. Soepratignja, Teknik Pembuatan Akta Kontrak, h. 135-136.

${ }^{11}$ Damang Averroes Al-Khawarizmi, "Tujuan Tanda Tangan" dalam www.negarahukum.com diakses tanggal 22 Desember 2016.
}

dalam pengertian akta, maka surat itu harus ditandatangani, keharusan tanda tangan ini tersirat dalam Pasal 1869 KUHPerdata, yang berbunyi :

Suatu akta yang tidak dapat diperlakukan sebagai akta otentik, baik karena tidak berwenang atau tidak cakapnya pejabat umum yang bersangkutan maupun karena cacat dalam bentuknya, mempunyai kekuatan sebagai tulisan di bawah tangan bila ditandatangani oleh para pihak. ${ }^{12}$

Jadi, suatu dokumen atau akta yang telah ditandatangani dan diakui kebenarannya mempunyai kekuatan pembuktian yang sama seperti akta otentik. Keharusan adanya tanda tangan tidak lain bertujuan untuk membedakan antara akta yang satu dengan akta yang lain, jadi fungsi tanda tangan pada suatu akta adalah untuk memberi ciri sebuah akta ${ }^{13}$ karena identifikasi dapat dilihat dari tanda tangan yang dibubuhkan pada akta tersebut.

Tanda tangan pada suatu akta sesungguhnya mempunyai dua fungsi hukum dasar, yaitu :

1. Tanda identitas penandatangan

2. Sebagai tanda persetujuan dari penandatangan terhadap kewajiban-kewajiban yang melekat pada akta.

Berdasarkan kedua fungsi hukum ini maka dapat ditarik suatu kesimpulan bahwa tanda tangan adalah sebuah identitas yang berfungsi sebagai tanda persetujuan terhadap kewajiban-kewajiban yang melekat pada akta. ${ }^{14}$

Dalam putusan HR yang dikemukakan oleh Pitlo terdapat berbagai bentuk tanda tangan yang dibenarkan oleh hukum antara lain: ${ }^{15}$

1. menuliskan nama penandatangan dengan atau tanpa menambah nama kecil;

2. tanda tangan dengan cara menuliskan nama kecil saja dianggap cukup;

3. ditulis tangan oleh penandatangan, tidak dibenarkan dengan stempel huruf cetak;

4. dibenarkan mencantumkan kopi tanda tangan

12 Pasal 1869 KUHPerdata,

${ }^{13}$ Ayu Riskiana Dinaryanti, "Tinjauan Yuridis Legalisasi Akta Di Bawah Tangan Oleh Notaris", Jurnal Imu Hukum Legal Opinion, Vol. 1, No. 3 (2013), 5.

${ }^{14}$ Hatta Isnaini Wahyu Utomo, 'Penggunaan Surrogate Sebagai Pengganti Tanda Tangan Dalam Akta Notaris Dan Implikasinya Terhadap Kedudukan Akta", dalam www.m-notariat.narotama.ac.id diakses tanggal 22 Desember 2016 pukul 09:36.

${ }^{15}$ Damang Averroes Al-Khawarizmi, "Tujuan Tanda Tangan" dalam www.negarahukum.com diakses tanggal 22 Desember 2016. 
si penandatangan dengan syarat:

a) orang yang mencantumkan kopi itu, berwenang untuk itu dalam hal ini orang itu sendiri; atau

b) orang yang mendapat kuasa atau mandat dari pemilik tanda tangan.

5. dapat juga mencantumkan tanda tangan dengan mempergunakan karbon.

Sedangkan penggunaan meterai atas surat perjanjian telah dikenal di Indonesia sejak zaman penjajahan Belanda. Di zaman penjajahan Belanda, ada banyak demang (jabatan setingkat lurah) yang dipecat oleh Pemerintah Belanda karena lalai menjalankan tugasnya memungut Bea Meterai atas dokumen yang terhutang. Sebelum dipecat oleh pihak penjajah ia (demang) diarak mengelilingi pasar dengan tangan terborgol sehingga menjadi bahan tontonan masyarakat. Kejadian ini menjadi bahan pembelajaran yang efektif kepada masyarakat yang secara mayoritas masih buta huruf, tidak memiliki ataupun tanpa perlu membaca staatsblad 1817 No. 50 (Pemungutan Bea Meterai 1817) ataupun staatsblad 1885 No. 131 (ordonansi pemungutan Bea Meterai di Hindia-Belanda) ataupun staatsblad 1921 No. 498 (aturan Bea Meterai 1921/zegelverordening 1921). ${ }^{16}$

Dengan kejadian tersebut, masyarakat menjadi sadar bahwa surat perjanjian ataupun pernyataan harus dimeteraikan. Masyarakatpun membuat kesimpulan sendiri (anggapan) bahwa suatu dokumen atau surat perjanjian tanpa meterai adalah tidak sah, sehingga menjadi suatu anggapan yang turun-temurun sampai hari ini masyarakat menganggap bahwa suatu dokumen atau surat perjanjian tanpa meterai adalah tidak kuat atau tidak sah.

Salah satu budaya yang tumbuh di masyarakat adalah anggapan/persepsi bahwa surat perjanjian adalah sah jika surat perjanjian tersebut lunas Bea Meterai. Budaya tersebut baik jika dihubungkan dengan kepatuhan pajak, akan tetapi jika dihubungkan dengan kesadaran hukum maka budaya tersebut kurang bagus. Sah atau tidaknya suatu perjanjian ditentukan oleh Pasal $1320 \mathrm{KUH}$ Perdata tidak ditentukan oleh pelunasan Bea Meterai.

\footnotetext{
${ }^{16}$ Mega Tumilaar, "Fungsi Meterai Dalam Memberikan Kepastian Hukum Terhadap Surat Perjanjian”, h. 61.
}

Pasal 1320 KUH Perdata menentukan empat syarat sahnya perjanjian yaitu: ${ }^{17}$

1. Kesepakatan

Yang dimaksud dengan kesepakatan di sini adalah adanya rasa ikhlas atau saling memberi dan menerima atau sukarela di antara pihak-pihak yang membuat perjanjian tersebut. Kesepakatan tidak ada apabila kontrak dibuat atas dasar paksaan, penipuan atau kekhilafan.

\section{Kecakapan}

Kecakapan di sini artinya para pihak yang membuat kontrak haruslah orang-orang yang oleh hukum dinyatakan sebagai subyek hukum. Pada dasarnya semua orang menurut hukum cakap untuk membuat kontrak. Yang tidak cakap adalah orang-orang yang ditentukan hukum, yaitu anak-anak, orang dewasa yang ditempatkan di bawah pengawasan (curatele), dan orang sakit jiwa. Anak-anak adalah mereka yang belum dewasa yang menurut Undang-undang Nomor 1 Tahun 1974 tentang Perkawinan belum berumur 18 (delapan belas) tahun. Meskipun belum berumur 18 (delapan belas) tahun, apabila seseorang telah atau pernah kawin dianggap sudah dewasa, berarti cakap untuk membuat perjanjian.

3. Hal tertentu

Hal tertentu maksudnya objek yang diatur kontrak tersebut harus jelas, setidak-tidaknya dapat ditentukan. Jadi tidak boleh samar-samar. Hal ini penting untuk memberikan jaminan atau kepastian kepada pihak-pihak dan mencegah timbulnya kontrak fiktif. Misalnya jual beli sebuah mobil, harus jelas merk apa, buatan tahun berapa, warna apa, nomor mesinnya berapa, dan sebagainya. Semakin jelas semakin baik. Tidak boleh misalnya jual beli sebuah mobil saja, tanpa penjelasan lebih lanjut.

4. Sebab yang dibolehkan

Maksudnya isi kontrak tidak boleh bertentangan dengan perundang-undangan yang sifatnya memaksa, ketertiban umum, dan/atau kesusilaan. Misalnya jual beli bayi adalah tidak sah karena bertentangan dengan norma-norma tersebut.

Bea materai adalah pajak yang dikenakan terhadap dokumen yang menurut undang-undang bea materai menjadi objek bea materai. Dokumen yang menjadi objek bea materai harus sudah

\footnotetext{
${ }^{17}$ Meria Utama, Hukum Ekonomi Internasional (Jakarta: PT. Fikahati Aneska, 2012), h. 70.
} 
dibubuhi benda materai atau pelunasan bea materai sebelum dokumen itu digunakan. ${ }^{18}$

Berdasarkan Peraturan Pemerintah No. 24 Tahun 2000 dalam Pasal 2 sampai dengan Pasal 4 dapat diketahui bahwa ada 2 macam nilai bea materai, yaitu Rp 3.000,00 (tiga ribu rupiah) dan Rp 6.000,00 (enam ribu rupiah). Dalam Pasal 2 Peraturan Pemerintah No. 13 Tahun 1985 disebutkan bahwa suatu dokumen atau surat yang isinya mengandung nilai uang atau harga nominal sampai dengan Rp 250.000,00 (dua ratus lima puluh ribu rupiah) tidak dikenakan bea materai. Akan tetapi apabila lebih dari Rp 250.000,00 (dua ratus lima puluh ribu rupiah) sampai dengan $\mathrm{Rp}$ 1.000.000,00 (satu juta rupiah), dikenakan bea materai dengan tarif Rp 3.000,00 (tiga ribu rupiah). Selanjutnya Pasal tersebut menyatakan bahwa dokumen yang mempunyai harga nominal lebih dari Rp 1.000.000,00 (satu juta rupiah) dikenakan bea materai dengan tarif $\mathrm{Rp}$ 6.000,00 (enam ribu rupiah). ${ }^{19}$

Bea Meterai menurut UU Bea Meterai 1985 tidak bersifat sebagai penggantian jasa. Pemerintah mengenakan Bea Meterai atas dokumen tidak ada imbalan secara langsung yang diberikan oleh Pemerintah kepada pembayar Bea Meterai. Dalam melakukan suatu perbuatan, adanya suatu keadaan atau kenyataan (peristiwa) tidak diharuskan seseorang membuat suatu dokumen untuk itu. Dengan demikian dapatlah diambil kesimpulan bahwa jika tidak dibuat dokumen tidak ada masalah pengenaan Bea Meterai atau disingkat: tiada dokumen, tiada Bea Meterai. Objek Bea Meterai bukanlah perbuatan hukumnya sendiri, seperti perbuatan jual beli, menerima uang, melakukan perborongan pekerjaan dan sebagainya melainkan dokumen yang dibuat untuk membuktikan adanya perbuatan itu seperti surat perjanjian. Sebagaimana diutarakan di atas bahwa Objek Bea Meterai adalah dokumen, tetapi tidak semua dokumen dikenakan Bea Meterai. Yang dikenakan Bea Meterai hanya dokumen yang disebut dalam Undang-undang saja, yaitu terbatas pada dokumen yang disebut dalam Pasal 2 UU Bea Materai 1985.

Dalam Pasal 2 Undang-undang No. 13 Tahun 1985 tentang Bea Meterai disebutkan bahwa Bea

\footnotetext{
${ }^{18}$ Aswin Wahyu Ramadhan,. dkk, "Potensi Pajak Penerangan Jalan Dan Kontribusinya Pada Pajak Daerah Kota Malang Periode 2011-2013", Jurnal Perpajakan (JEJAK), Vol. 8, No. 1 (2016), 3.

${ }^{19}$ F.X. Suhardana, Contract Drafting (Yogyakarta: Universitas Atma Jaya, 2009), 148
}

Meterai dikenakan atas dokumen yang berbentuk: 1. surat perjanjian dan surat-surat lainnya yang dibuat dengan tujuan untuk digunakan sebagai alat pembuktian mengenai perbuatan, kenyataan atau keadaan yang bersifat perdata;

2. akta-akta notaris termasuk salinannya;

3. akta-akta yang dibuat oleh Pejabat Pembuat Akta Tanah termasuk rangkap-rangkapnya;

4. surat yang memuat jumlah uang lebih dari Rp. 1.000.000 (satu juta rupiah):

a) yang menyebutkan penerimaan uang;

b) yang menyatakan pembukuan uang atau penyimpanan uang dalam rekening di bank;

c) yang berisi pemberitahuan saldo rekening di bank;

d) yang berisi pengakuan bahwa hutang uang seluruhnya atau sebagiannya telah dilunasi atau diperhitungkan;

5. surat berharga seperti wesel, promes, aksep, dan cek yang harga nominalnya lebih dari Rp. 1.000.000,- (satu juta rupiah);

6. efek dengan nama dan dalam bentuk apapun, sepanjang harga nominalnya lebih dari Rp. 1.000.000,- (satu juta rupiah).

Dengan demikian maka tiadanya materai dalam suatu surat perjanjian maka tidak berarti perbuatan hukumnya tidak sah, melainkan hanya surat perjanjiannya tidak memenuhi persyaratan sebagai alat pembuktian.

Apabila dokumen kontrak yang dibuat tanpa dibubuhi materai, atau dibuat dikertas biasa bukan kertas materai akan dipergunakan sebagai alat bukti di pengadilan, harus lebih dahulu dilakukan pemateraian atau nachrageling (Pasal 8 UU No. 13 Tahun 1985). ${ }^{20}$ Bea materai dapat juga dilunaskan dengan cara lain yang ditetapkan oleh Meneteri Keuangan. Dengan Keputusan Nomor : 104/ KMK.04/1986 tanggal 22 Februari 1986, oleh Menteri Keuangan telah ditetapkan, bahwa bea materai dapat juga dilunaskan dengan menggunakan "mesin teraan materai" (taxograph) atau "alat lain" dengan teknologi tertentu.

Menurut ketentuan Pasal 7 UU Bea Materai, pembubuhan tanda tangan dilakukan sedemikian rupa, sehingga sebagian dari tanda tangan berada di atas materai tempel. Perlu diketahui, bahwa atas suatu lembar materai hanya boleh terlintas satu tanda tangan. Pemateraian dengan menggunakan kertas

${ }^{20}$ Ibid., h. 149. 
materai (kertas zegel) cukup dengan menggunakan kertas zegel tersebut sebagai dokumen. Apabila nilai pajak yang tertera dalam kertas materai itu kurang dari besarnya bea materai yang terutang, kekurangan tersebut dapat dilunaskan dengan cara menambahkan materai tempel secukupnya. ${ }^{21}$

Surat perjanjian diperlukan syarat bahwa surat atau dokumen itu dibuat dengan tujuan untuk dipakai sebagai alat bukti. Jika surat dibuat tidak untuk tujuan itu sekalipun mempunyai daya bukti, maka tidak langsung harus dikenakan Bea Meterai. Yang perlu dibuktikan ialah perbuatan, kenyataan atau keadaan yang bersifat perdata. Dengan perkataan lain dokumen itu adalah dokumen perdata.

\section{Eksistensi Kontrak Franchise (Waralaba)}

Lembaga franchise pertama kali dikenal di Amerika Serikat, yaitu kurang lebih satu abad yang lalu ketika perusahaan bir memberikan lisensi kepada perusahaan-perusahaan kecil untuk mendistribusikan bir produksi pabrik yang bersangkutan, serta distribusi mobil dan bensin. Franchise pada saat itu dilakukan pada tingkat distributor. ${ }^{22}$

Kemudian, di Prancis pada tahun 1200an, penguasa negara dan penguasa gereja mendelegasikan kekuasaan mereka kepada para pedagang dan ahli pertukangan melalui apa yang dinamakan "diartes de franchise", yaitu hak untuk menggunakan atau mengolah hutan yang berada di bawah kekuasaan negara atau gereja. Sebagai imbalannya, penguasa negara atau penguasa gereja menuntut jasa tertentu atau uang. Pemberian hak tersebut diberikan juga kepada para pedagang dan ahli pertukangan untuk penyelenggaraan pasar dan pameran,dengan imbalan sejumlah uang. ${ }^{23}$

Zaman franchise modern baru dimulai pada akhir 1940-an dan awal 1950-an. Hal ini terlihat dari berkembangnya Mc Donald's (1955), Carvel Ice Cream (1945), Jhon Robert Power (1955), Kentucky Fried Chicken (1952), dan lain-lain. Sejak tahun 1972 sampai dengan tahun 1988, usaha franchise mengalami peningkatan yang sangat besar di Amerika Serikat, hal ini tampak dari banyaknya

\footnotetext{
${ }^{21}$ Paulus J. Soepratignja, Teknik. Pembuatan Akta Kontrak, h. 134-135.

${ }^{22}$ Salim H.S., Perkembangan Hukum Kontrak Innominaat di Indonesia (Jakarta: Sinar Grafika, 2003), h. 166.

${ }^{23}$ Adesia Adilman, "Perlindungan Hukum Haki Dalam Perjanjian Waralaba”, Tesis Universitas Diponegoro Semarang (2010), h. 26.
}

usaha franchise yang berkembang di negara tersebut. Jumlah unit usaha franchise yang berkembang di Amerika Serikat sebanyak 368.458 unit usaha. Di negara lain juga telah berkembang unit usaha franchise, seperti di Australia sebanyak 10.303 unit usaha, Kanada sebanyak 45.000 unit usaha, Jepang sebanyak 102.397 unit usaha, dan Inggris sebanyak 16.600 unit usaha.

Di Indonesia, sistem bisnis dengan franchise mulai berkembang sejak tahun 1980-an. Pada saat ini sudah banyak franchise asing yang masuk ke Indonesia, baik dalam perdagangan barang maupun jasa. Selain itu beberapa pengusaha Indonesia juga telah mulai mengembangkan domestic franchise, seperti Es Teler 77, Salon Rudi Hadisuwarno, Ny. Tanzil Fried Chiken dan Steak, Kios Modern (Kimo), dan lain-lain. ${ }^{24}$

Franchise berasal dari bahasa Latin, yaitu Francorum rex yang artinya "bebas dari ikatan", yang mengacu pada kebebasan untuk memiliki hak usaha. Sedangkan pengertian franchise berasal dari bahasa Perancis abad pertengahan, diambil dari kata "franc" (bebas) atau "francher" (membebaskan), yang secara umum diartikan sebagai pemberian hak istimewa.

Dalam praktiknya, istilah franchise dipopulerkan oleh Amerika Serikat. Sedangkan dalam bahasa Indonesia, franchise diterjemahkan sebagai "waralaba" yang berarti "lebih untung". "Wara" berarti "lebih" sedangkan "laba" berarti "untung" istilah waralaba atau franchise berakar dari sejarah masa silam praktik bisnis di Eropa. Pada masa lalu bangsawan di Eropa diberikan wewenang oleh raja untuk menjadi tuan tanah di daerahdaerah tertentu. Di daerah tersebut, bangsawan dapat memanfaatkan tanah yang akan dikuasainya asalkan membayar imbalan pajak/upeti yang harus dikembalikan kepada kerajaan. Sistem tersebut menyerupai royalty seperti layaknya waralaba pada saat ini. ${ }^{25}$

Dalam Peraturan Pemerintah Republik Indonesia Nomor 16 Tahun 1997 waralaba diartikan sebagai sebuah perikatan di mana salah satu pihak diberikan hak untuk memanfaatkan dan/atau menggunakan hak atas kekayaan intelektual atau penemuan atau ciri khas usaha yang dimiliki pihak

\footnotetext{
${ }^{24}$ Salim H.S., Perkembangan Hukum Kontrak Innominaat di Indonesia, h. 167.

${ }^{25}$ Tami Rusli, "Analisis Terhadap Perjanjian Waralaba (Franchise) Usaha Toko Alfa Mart", Keadilan Progresif, Vol. 6, No. 1 (Maret 2015), h. 64.
} 
lain dengan suatu imbalan berdasarkan persyaratan yang ditetapkan pihak lain tersebut, dalam rangka penyediaan dan/atau penjualan barang dan jasa.

Sedangkan menurut Peraturan Pemerintah Republik Indonesia Nomor 42 Tahun 2007 waralaba diartikan sebagai hak khusus yang dimiliki oleh orang perseorangan atau badan usaha terhadap sistem bisnis dengan ciri khas usaha dalam rangka memasarkan barang dan/atau jasa yang telah terbukti berhasil dan dapat dimanfaatkan dan/atau digunakan oleh pihak lain berdasarkan perjanjian waralaba. ${ }^{26}$

Franchise sebagai suatu cara melakukan kerjasama di bidang bisnis antara dua atau lebih perusahaan, satu pihak bertindak sebagai franchisor dan pihak lain sebagai franchisee, dimana di dalamnya diatur bahwa pihak franchisor sebagai pemilik suatu merek dan teknologi, memberikan haknya kepada franchisee untuk melakukan kegiatan bisnis berdasarkan merek dan teknologi tersebut. ${ }^{27}$

Franchise merupakan sistem usaha yang memiliki ciri khas tertentu berupa jenis produk dan bentuk yang diusahakan, identitas perusahaan (logo, desain, merek bahkan termasuk pakaian dan penampilan karyawan perusahaan), rencana pemasaran dan bantuan operasional. ${ }^{28}$

Pietra Sarosa, salah seorang pengamat waralaba mengatakan keunggulan utama waralaba adalah karena sistem yang disediakan. "Dengan demikian seorang pemodal yang akan menjalankan investasi tidak harus memulai lagi dari nol’. Banyak penelitian yang memperlihatkan bahwa $90 \%$ usaha bisnis itu gagal dalam tiga tahun pertama. Dalam menjalankan bisnis yang sudah memiliki sistem tertentu, seperti yang disediakan waralaba para pebisnis atau investor bebas dari risiko trial and error. Mungkin karena itu seorang penulis, Bob Brooke mengatakan keuntungan utama dalam bisnis waralaba adalah karena risikonya yang sangat minimal. ${ }^{29}$

\footnotetext{
${ }^{26}$ Djarot Pribadi, "Akibat Hukum Perjanjian Waralaba yang dilakukan saat Proses Pendaftaran Merek," Jurnal Fakultas Hukum Universitas Narotama Surabaya, Vol. XX, No. 20 (2011), h. 88.

${ }^{27}$ Giri Prasadha, "Kajian Yuridis Pelaksanaan Pelaksanaan Waralaba Pada Texas Chicken Padang," dalam www. jurnal.unitas-pdg.ac.id diakses tanggal 22 Desember 2016.

${ }^{28}$ Adesia Adilman, "Perlindungan Hukum Haki Dalam Perjanjian Waralaba", h. 22.

${ }^{29}$ Camelia Malik, "Implikasi Hukum Adanya Globalisasi Bisnis Franchise", Jurnal Hukum Vol. 14, No. 1 Januari 2007), h. 105.
}

East Asian Executive Report pada tahun 1983 menggolongkan franchise menjadi 3 macam, yaitu sebagai berikut: ${ }^{30}$

1. Product franchise, di sini penerima franchise hanya bertindak mendistribusikan saja produk dari partnernya dengan pembatasan areal, seperti pengecer bahan bakar Shell atau British Pertroleum;

2. Processing franchise or manufacturing franchise, di sini pemberi franchise hanya memegang peranan memberi know-bow, dari suatu proses produksi seperti minuman Coca Cola atau Fanta;

3. Bussiness format/system franchise, di sini pemberi franchise sudah memiliki cara yang unik dalam menyajikan produk dalam satu paket, kepada konsumen. Seperti Dunkin Donuts, KFC, Pizza Hut, dan lain-lain.

Secara umum ada beberapa keuntungan yang dapat diperoleh franchisee dalam sistem waralaba, yaitu sebagai berikut: ${ }^{31}$

1. Modal yang diperlukan untuk usaha waralaba lebih sedikit dibandingkan dengan usaha mandiri yang independen.

2. Acapkali tidak harus memiliki pengetahuan tentang bisnis yang akan digeluti karena franchisor melakukan pelatihan.

3. Resiko bisnis berkurang karena nama dan produk franchisor sudah dikenal dan memiliki goodwill. Hal ini karena adanya bantuan dan dukungan usaha terus menerus yang diberikan oleh franchisor.

4. Adanya hak untuk mengelola bisnis yang sudah mapan dan memiliki identitas atau merek dagang yang legal dan populer sehingga tidak harus mengembangkan ide dan citra produk yang memerlukan waktu dan tenaga.

5. Franchisee hanya memerlukan proses belajar yang singkat, tujuan yang terarah, serta kekuatan dalam kegiatan promosi yang efisien.

6. Produk atau jasa yang sudah terkenal serta merek dagang yang sudah besar.

7. Memperoleh dukungan managemen dan dukungan promosi.

8. Memperoleh pelatihan managemen (pemasaran, produksi, keuangan, dan SDM).

\footnotetext{
${ }^{30}$ Salim H.S., Perkembangan Hukum Kontrak Innominaat di Indonesia, 168-169.

${ }^{31}$ Adrian Sutedi, Hukum Waralaba (Bogor: Ghalia Indonesia, 2008), 131-132.
} 
9. Adanya kemudahan dalam memperoleh pinjaman kepada pihak ketiga bila waralabanya sudah teruji di pasar.

10. Memiliki sistem pemasaran yang telah teruji.

11. Resiko kegagalan bisnis yang relatif rendah.

Dengan berbagai keuntungan yang telah dijelaskan, tidak mengherankan waralaba menjadi lirikan pengusaha-pengusaha baru untuk mengembangkan ladang bisnisnya.

Sedangkan kerugian bagi franchisee ialah sebagai berikut: ${ }^{32}$

1. Meski memiliki usaha sendiri, kebijakan umumnya masih ditentukan oleh franchisor sehingga untuk memperoleh sistem yang baku memerlukan proses yang birokratis.

2. Biasanya franchisor mengontrol berbagai aspek pengelolaan bisnis, terkadang malah terkesan terlalu membatasi.

3. Untuk mendapatkan hak waralaba, franchisee harus mempertimbangkan sumber dana untuk pembayaran royalti yang tinggi.

4. Kebijakan franchisor tidak selalu disampaikan kepada franchisee secara kontinyu serta perlu kreativitas dan pemahaman sendiri dalam segi managemen usaha.

5. Pihak franchisor memiliki kedudukan yang lebih tinggi daripada franchise, hal ini disebabkan karena franchisor sebagai pemilik usaha yang menyewakan usahanya tersebut kepada franchisee dengan ketentuan bahwa pihak franchisee tidak akan menyewakannya kepada pihak lain. Kedudukan ini membuat franchisor dapat menentukan isi perjanjian bahkan memutuskan perjanjian secara sepihak.

Pemutusan kontrak dapat disebabkan karena wanprestasi atau kealpaan dari pihak franchisor maupun wanprestasi atau kealpaan dari pihak franchisee. Biasanya alasan franchisor memutuskan perjanjian karena pihak franchisee melanggar isi perjanjian yang telah dibuat. Misalnya jika franchisee tidak memenuhi sales quota minimum yang telah disepakati, franchisor dapat memutuskan perjanjian tersebut. Hal lain yang mungkin juga terjadi misalnya:

1. Franchisee menjadi terutang atau tidak mampu membayar utang kepada franchisor (insolven);

2. Terlambat melakukan laporan royalty;

3. Melakukan pelanggaran atau kerahasiaan;

${ }^{32}$ Ibid., 132.
4. Gagal membayar royalti;

5. Melakukan tindakan di luar standar kualitas dan jasa.

Salah satu resiko dalam kontrak waralaba adalah bentuk kontrak yang merupakan kontrak baku yang dibuat oleh franchisor dengan menetapkan syarat-syarat dan standar yang harus diikuti oleh franchisee yang memungkinkan franchisor dapat membatalkan perjanjian. Franchisor dapat memanfaatkan kedudukan franchisee untuk menguji pasar, setelah mengetahui bahwa kondisi pasar menguntungkan, maka franchisor dapat memutuskan perjanjian dan membuka tempat usaha sendiri di wilayah franchisee. ${ }^{33}$

Lebih lanjut dalam hal franchisee menyatakan dirinya bangkrut atau dinyatakan bersalah karena adanya masalah kriminal, franchisor dapat memutuskan perjanjian waralaba tanpa harus memberikan catatan kepada franchisee. ${ }^{34}$

Keuntungan bagi franchisor untuk mewaralabakan bisnisnya antara lain sebagai berikut: ${ }^{35}$

1. Modal sepenuhnya berasal dari franchisee, yang juga dipakai untuk menjalankan bisnis tersebut.

2. Franchisor menerima persentase dari penghasilan kotor dan tidak memiliki keuntungan dan kerugian dari franchisee.

3. Franchisee atau orang yang ditunjuk franchisee terjun sendiri untuk menangani operasional usahanya.

4. Franchisee membayar biaya pelatihan.

5. Usahanya dapat cepat berkembang, tetapi dengan menggunakan modal dan motivasi dari franchisee.

6. Mengurangi biaya untuk mengelola merek, karena merek adalah time consume to develop, dan sebagainya.

Sedangkan kerugian bagi franchisor dalam bisnis waralaba ialah sebagai berikut: ${ }^{36}$

1. Franchisor tidak mudah mengontrol franchisee sehingga sulit bagi franchisor untuk mengadakan inovasi baru.

\footnotetext{
${ }^{33}$ Munir Fuady, Konsep Hukum Perdata (Jakarta: PT. RajaGrafindo Persada, 2004), h. 85-86.

${ }^{34}$ Lannemey, "Akibat Hukum Pemutusan Perjanjian Franchise Secara Sepihak Oleh Franchisor Sebelum Berakhirnya Kontrak", h. 166.

${ }^{35}$ Ibid., h. 133.

${ }^{36}$ Ibid., h. 134.
} 
2. Timbul kesulitan bagi franchisor karena biasanya timbul harapan yang terlalu tinggi dari franchisee untuk mendapatkan keuntungan yang sebesarbesarnya dalam waktu sesingkat-singkatnya.

3. Jika da kenaikan dari segi biaya, biasanya franchisor tidak mudah untuk meyakinkan franchisee.

4. Bisa menghancurkan reputasi franchisor jika ternyata franchisee yang dipilih tidak tepat.

5. Mengingat ikatan waralaba biasanya untuk jangka waktu yang lama, maka apabila franchisor ingin mengakhiri perjanjian waralaba secara sepihak, tidak mudah untuk mengakhirinya tanpa alasan-alasan yang sah.

\section{Urgensi Tanda Tangan dan Materai Dalam Memberikan Kepastian Hukum Terhadap Kontrak Waralaba}

Salah satu fungsi kontrak waralaba yaitu memiliki fungsi yuridis. Fungsi yuridis kontrak waralaba adalah dapat memberikan kepastian hukum bagi para pihak. Sama seperti perjanjian lainnya, dalam pelaksanaan perjanjian franchise sangat terbuka lebar kemungkinan terjadi permasalahan atau perselisihan. Wanprestasi dalam kontrak waralaba dapat dilakukan oleh pihak pemberi waralaba (franchisor) maupun pihak penerima waralaba (franchisee). Wanprestasi yang dilakukan oleh pihak franchisor antara lain: tidak melakukan pembinaan manajemen kepada pihak franchisee, sedangkan wanprestasi dari pihak franchisee dapat berupa tidak membayar fee, melakukan pelayanan yang tidak sesuai dengan ketentuan yang diatur dalam perjanjian waralaba. ${ }^{37}$

Walaupun dalam perjanjian tersebut telah disebutkan hak dan kewajiban masing-masing pihak, namun salah satu pihak seringkali tidak dapat melaksanakan isi perjanjian yang telah disepakati seperti pemutusan secara sepihak sebuah kontrak perjanjian (franchiseagreement) antara pihak franchisor dengan pihak franchise. ${ }^{38}$

Dampak dari pemutusan perjanjian atau kontrak secara sepihak oleh franchisor pastinya sangat merugikan franchisee. Sehingga tidak menutup kemungkinan franchisee untuk menuntut

\footnotetext{
${ }^{37}$ Tulus Prijanto, "Waralaba Dan Hukum”, Jurisprudence, Vol. 1, No. 1 (Juli 2012), h. 194.

${ }^{38}$ Merry T. J. Ruauw, "Perlindungan Hukum Terhadap Franchishor Dan Franchisee Dalam Perjanjian Franchise", Jurnal Vol. 1, No.1 (April-Juni 2013), h. 110.
}

ganti rugi atas kerugian yang dideritanya. Apabila franchisee menuntut ganti rugi, maka franchisor harus membayar kerugian tersebut. Demikian sebaliknya apabila wanprestasi atau kealpaan disebabkan oleh franchisee maka franchisor juga dapat menuntut ganti rugi. ${ }^{39}$

Perjanjian waralaba merupakan salah satu aspek perlindungan hukum kepada para pihak dari perbuatan merugikan pihak lain. Hal ini dikarenakan perjanjian tersebut dapat menjadi dasar hukum yang kuat untuk menegakkan perlindungan hukum bagi para pihak yang terlibat dalam sistem waralaba. Jika salah satu pihak melanggar isi perjanjian, maka pihak lain dapat menuntut pihak yang melanggar tersebut sesuai dengan hukum yang berlaku. ${ }^{40}$

Agar kontrak waralaba tersebut dapat dijadikan bukti maka kontrak tersebut harus mencantumkan konsensus dari kedua belah pihak, yaitu franchisor dan franchisee, yang dalam hal ini bentuk persetujuan tersebut dinyatakan dengan pembubuhan tanda tangan dalam kontrak tersebut. Dengan pembubuhan tanda tangan tersebut, maka para pihak dianggap mengetahui dan menyetujui baik tempat dan waktu serta isi perjanjian yang dibuat tersebut. Tanda tangan juga menunjukkan kesengajaan para pihak untuk membuat suatu kontrak sebagai suatu bukti atas suatu peristiwa.

Tanda tangan saja belum memenuhi persyaratan agar kontrak yang dibuat tesebut dapat digunakan sebagai alat bukti di pengadilan. Alat bukti tertulis yang diajukan dalam acara perdata harus dibubuhi meterai. ${ }^{41}$ Oleh karena itu untuk menjamin kepastian hukum dari kontrak waralaba, sebaiknya saat penandatanganan dibubuhi materai, agar sewaktu-waktu franchisor atau franchisee ingin mempergunakan kontrak itu sebagai alat pembuktian maka dokumen kontrak waralaba tersebut telah memenuhi syarat sebagai alat pembuktian.

\section{Penutup}

Berdasarkan analisis kajian diatas, maka dapat disimpulkan bahwa fungsi tanda tangan dan meterai dalam kontrak waralaba adalah sebagai pemberi

\footnotetext{
${ }^{39}$ Ibid., h. 166.

${ }^{40}$ Lathifah Hanim, "Perlindungan Hukum Haki Dalam Perjanjian Waralaba Di Indonesia," Jurnal Hukum, Vol. XXVI, No. 2 (Agustus 2011), 580.

${ }^{41}$ Komang Kusdi Wartanaya dan Nyoman A. Martana, "Kekuatan Yuridis Meterai Dalam Surat Perjanjian", Jurnal Hukum, Vol. 01, No. 09 (September 2013), 4.
} 
kepastian hukum di depan pengadilan. Tanda tangan merupakan bentuk konsensus/kesepakatan sekaligus kesengajaan antara kedua belah pihak dan dengan pembubuhan tanda tangan tersebut, maka para pihak dianggap mengetahui dan menyetujui isi kontrak yang dibuat tersebut. Agar kontrak yang dibuat tersebut dapat digunakan sebagai alat bukti di pengadilan, selain membubuhkan tanda tangan, kontrak waralaba tersebut juga harus dibubuhi meterai.

Namun dalam hal ini harus ditegaskan bahwa sah tidaknya suatu surat perjanjian tidak ditentukan oleh ada tidaknya meterai namun oleh Pasal 1320 KUH Perdata. Persepsi dan kebiasaan yang keliru dari masyarakat selama ini mengenai penggunaan meterai untuk syarat sahnya suatu surat perjanjian perlu dirubah dan diluruskan. Peran serta Pemerintah maupun semua pihak yang memiliki pengetahuan hukum sangat diperlukan dalam mengatasi hal ini untuk mencegah kekeliruan yang sama pada generasi berikutnya.

\section{Daftar Pustaka}

Adilman, Adesia. "Perlindungan Hukum Haki Dalam Perjanjian Waralaba", Tesis, Semarang: Universitas Diponegoro, 2010.

Averroes Al-Khawarizmi, Damang. “Tujuan Tanda Tangan" dalam www.negarahukum.com diakses tanggal 22 Desember 2016.

Fuady, Munir. Konsep Hukum Perdata, Jakarta: PT. RajaGrafindo Persada, 2004.

Handayani, Tutwuri. "Pengakuan Tanda Tangan Pada Suatu Dokumen Elektronik Di Dalam Pembuktian Hukum Acara Perdata Di Indonesia", Tesis Universitas Diponegoro Semarang, 2009.

Hanim, Lathifah. "Perlindungan Hukum Haki Dalam Perjanjian Waralaba Di Indonesia," Jurnal Hukum, Vol. XXVI, No. 2, Agustus 2011.

H.S., Salim. Perkembangan Hukum Kontrak Innominaat di Indonesia, Jakarta: Sinar Grafika, 2003.

Isnaini Wahyu Utomo, Hatta. "Penggunaan Surrogate Sebagai Pengganti Tanda Tangan Dalam Akta Notaris Dan Implikasinya Terhadap Kedudukan Akta" dalam www.mnotariat.narotama.ac.id diakses tanggal 22 Desember 2016.
J. Soepratignja, Paulus. Teknik Pembuatan Akta Kontrak, Yogyakarta: Universitas Atma Jaya, 2007.

Kusdi Wartanaya, Komang, dan Nyoman A. Martana. "Kekuatan Yuridis Meterai Dalam Surat Perjanjian", Jurnal Hukum, Vol. 01, No. 09, September 2013.

Lannemey, "Akibat Hukum Pemutusan Perjanjian Franchise Secara Sepihak Oleh Franchisor Sebelum Berakhirnya Kontrak", Lex Privatum, Vol. III, No. 1, Jan-Mar 2015.

Malik, Camelia. "Implikasi Hukum Adanya Globalisasi Bisnis Franchise", Jurnal Hukum, Vol. 14, No. 1, Januari 2007.

Prasadha, Giri. "Kajian Yuridis Pelaksanaan Waralaba Pada Texas Chicken Padang," dalam www.jurnal.unitas-pdg.ac.id diakses tanggal 22 Desember 2016.

Pribadi, Djarot. "Akibat Hukum Perjanjian Waralaba yang dilakukan saat Proses Pendaftaran Merek," Jurnal Fakultas Hukum Universitas Narotama Surabaya, Vol. XX, No. 20, 2011.

Prijanto, Tulus. "Waralaba Dan Hukum", Jurisprudence, Vol. 1, No. 1, Juli 2012.

Riskiana Dinaryanti, Ayu. "Tinjauan Yuridis Legalisasi Akta Di Bawah Tangan Oleh Notaris", Jurnal Ilmu Hukum Legal Opinion, Vol. 1, No. 3, 2013.

Rusli, Tami. "Analisis Terhadap Perjanjian Waralaba (Franchise) Usaha Toko Alfa Mart", Keadilan Progresif, Vol. 6, No. 1, Maret 2015.

Santoso AZ, Lukman. Hukum Perikatan, Malang: Setara Press, 2016.

Suhardana, F.X. Contract Drafting, Yogyakarta: Universitas Atma Jaya, 2009.

Sutedi, Adrian. Hukum Waralaba, Bogor: Ghalia Indonesia, 2008.

Suwignyo, Hadi. "Keabsahan Cap Jempol Sebagai Pengganti Tanda Tangan Dalam Pembuatan Akta Otentik", Jurnal Studi Kenotariatan NOTARIUS, Vol. 1, No. 1, 2009.

Tumilaar, Mega. "Fungsi Meterai Dalam Memberikan Kepastian Hukum Terhadap Surat Perjanjian", Lex Privatum, Vol. III, No. 1, Jan-Mar 2015.

T. J. Ruauw, Merry. "Perlindungan Hukum Terhadap Franchishor Dan Franchisee 
Dalam Perjanjian Franchise", Jurnal Vol. 1, No.1, April-Juni 2013.

Utama, Meria. Hukum Ekonomi Internasional, Jakarta: PT. Fikahati Aneska, 2012.

Wahyu Ramadhan,. Aswin, dkk. "Potensi Pajak Penerangan Jalan Dan Kontribusinya Pada Pajak Daerah Kota Malang Periode 2011 2013", Jurnal Perpajakan (JEJAK), Vol. 8, No. 1, 2016. 